\title{
Does Political Ideology Affect the Growth of Indian Economy? (A Factor of FDI and Make in India as a Structural Transformation)
}

\author{
Anshul Sharma, Farman Ali
}

\begin{abstract}
The Bharatiya Janta Party (BJP) has started its second inning in June 2019, led by Prime Minister of India Shree Narendra Modi. During his first tenure the government has taken so many decisions to accelerate the growth of Indian Economy like launching of Make in India campaign, demonetization and GST Bill nonetheless from the beginning of their ruling the government has adopted the East Asian welfare economic model rather European to pursue social and structural transformation. In September 2014, Modi government launched a flagship project Make in India with an objective to set the Country as an eminent global manufacturing hub, to attract the FDI and world class manufacturer in India by making the business easy for foreign players. It is the perception of many economists that this campaigning has no meaning for Indian economy and it is only slogan and propaganda of this party. In this research paper we tried to check the effect of this maneuver on various economic barometers like FDI, GDP, Trade openness and foreign exchange etc and we also tried to give some recommendations to the government on the basis of the findings so that the campaign may be continued with full of energy and improvement. This is well acknowledged under the supervision of Prime Minister Shree Narendra Modi, the Foreign direct investment to India has grown up by $6 \%$ to 42 Billion USD with a brawny inflows in different sectors like communication, manufacturing and banking services , as per the report of United Nation India is top ranked country among the top twenty host economies of the world.
\end{abstract}

Index Terms: Make in India, Sector wise Growth, FDI \& Political Ideology

\section{INTRODUCTION}

In India we have huge amount of natural resources and aplenty of skilled and unskilled labor having requisite skills and determination. As all developed countries are looking east for outsourcing so India may become a preferred destination for outsourcing and for manufacturing activities. To cash this opportunity Indian Government started a campaign "make in India" with an objective that all the friendly investors of the country will choose our country as a preferred location for manufacturing and outsourcing activities.

The program started with an objective to augment the input of manufacturing sector in GDP through $16 \%$ to $25 \%$ till 2025 . With coverage of 25 sectors ranging from auto mobiles to IT, Make in India targeted the employment possibilities, doing business easily, and encourage innovation and promote blooming of skills. By such course of action India wants to attract the FDI and spread the message in all over world that if an investor comes to India then it will be a pleasant experience for him with minimum official procedure.

The nation wants to be in contour with the transfer of latest and updated technology as well as resources to make this program successful. The inflow of capital and expertise from outside across the border of India may strengthen the manufacturing and contribution to GDP of Indian economy. The program is also significant for huge jobless crowd from the point of view of their employment. Engagement of the manpower in aforesaid sector will reduce the unemployment. The opening of FDI into new sectors like Defense and Railway will give lifelong assistance rather than transitory results. With the commencement of promoting FDI, obsolete and slow process has converted in to transparent and user friendly system to drive investment proposals. Investor facilitation cell has been started for seeking regulatory approvals. To build strong relationship with our friendly nations and the nations whereabouts the capital formation is dynamic; A special team has been created for prompt pathway investment proposals. Although the Manufacturing corridors are being developed to make better the campaigning.

\section{LITERATURE REVIEW}

Bhattacharyya Jita \& Bhattacharyya Mousumi (2012) studied all factors of economic growth and enlighten the lifelong association among the FDI, goods \& service trade and economic growth of India. Abdul A., Morris R. (2011) found that two determinants, real estate business and export-import across borders, were correlated to FDI over last 6 consecutive year of the study (2000-2005) by taking combined sampling. Nevertheless quite a few factors were also responsible to push FDI in Asia during a range of years. Singh S., Singh M. (2011) observed the inclination of FDI inflow to India, during 1970 to 2007 by using the data of time series. The objective of this paper was to study the reasons on the far side of fluctuations in the FDI inflow to India and to seek out the root causes that are accountable for the alteration in the trends of FDI. Singh Y\& Bhatnagar A. (2011), find out in their research "FDI in India \& China" that both nations enjoy dynamic economic growth but FDI inflow in India was less than china. 


\section{Does Political Ideology Affect the Growth of Indian Economy? (A Factor of FDI and Make in India as a Structural Transformation)}

Agarwal G\& Khan M. A. (2011) search out that $1 \%$ hike in FDI reflect $0.07 \%$ growth in GDP of China and $0.02 \%$ upswing in India. They also concluded that the growth of China is exaggerated by FDI than India .Saini A., Law S. H \& Ahmad A. H. (2010), It has been clear by this study that FDI influenced the growth. Gerwin, M., \& Bergmann, C. (2012) analyzed a specific socio-cultural driving forces toward the growth of the nation by utilizing the natural resources. The success of Make in India is much needed for Indian economy. A paper by Dr T.V. Ramana, focused on the assumptions of classical theory of economics linking the demand \&supply of goods. He emphasized the issues of concerned sectors and analyzed worldwide response from the assorted researchers. In this paper 'Ramana' was able to show that by producing more the manufacturer will get more benefit but researcher was fail to show the future prospects and economic viability of the program.

Dr. Rajeshwari Shettar and S.M. Sheshgiri Commerce College for women showed in a global perspective that the program will be a game changer in the Automobiles, Biotechnology and Chemicals etc. The researchers emphasized in creation of employment by attracting regular global investors and nation should consciously work to attract FDI into R \& D so that the sustainable growth in economy can be maintained but how the FDI would have an effect on the Indian economy to be determined. Prof. Samridhi Goyal, Prabhjot Kaur and Kawalpreet Singh tried to show that how human being and financial inclusion may play a crucial role in the development of the nation. These authors were focused that by fostering improvement and minimizing brain deplete then how the objective of employment generation and economic development may be attained.

\section{Conclusion of literature review:}

1. The success of the program may be depends on demand inside and outside of the country so we have to be cautious about foreign investments.

2. India may be able to foster the growth of its manufacturing sector as well as nation may be able to generate employment and attract FDI.

3. With proper utilization of human resources and financial services of India may be converted into manufacturing hub.

\section{OBJECTIVES:}

1. To check the correlation among macroeconomic variables and FDI.

2. To develop a regression model to find out target areas where more focused approach is required to attract more FDI

3. To identify the gap between the political ideology of ruling parties with respect to socioeconomic variables. .

4. To see the trend of different sectors after initiation of Make in India campaign.

Source of Data: This study has deployed the secondary sources of data, were collected from 'Hand Book of statistics on the Indian economy', RBI reports and reports of IBEF. Data has also been collected through the reports of Govt. agencies and other agencies.

Period of study: The data of all economic variables has been taken for the financial year 2014-19.

\section{RESEARCH METHODOLOGY}

To complete the study we divided it in to four parts. To check the relationship between FDI and other major economic variables we used correlation coefficient. To find out target areas we developed a regression model. To see the trend of different sectors we used graphical method. To develop a basic forecast for different sectors we used least square.

Table-I Coefficient of Correlation

\begin{tabular}{|l|c|c|c|c|c|c|c|c|c|}
\hline \multicolumn{1}{|c|}{ Sr. No. } & 1 & 2 & 3 & 4 & $\mathbf{5}$ & 6 & 7 & 8 & 9 \\
\hline $\begin{array}{l}\text { Macroeconomic } \\
\text { Variables }\end{array}$ & GDP & T0 & Exports & Imports & IPI & $\begin{array}{l}\text { Exchange } \\
\text { Rate }\end{array}$ & GFCF & $\begin{array}{l}\text { Fiscal } \\
\text { Deficit }\end{array}$ & $\begin{array}{l}\text { Political } \\
\text { Ideology }\end{array}$ \\
\hline $\begin{array}{l}\text { Coefficient of } \\
\text { Correlation }\end{array}$ & 0.913 & 0.116 & 0.731 & 0.821 & 0.795 & 0.856 & 0.881 & 0.832 & 0.798 \\
\hline
\end{tabular}

a)Gross Domestic Product: GDP has strong positive correlation with FDI. It indicates the strong GDP growth, nonetheless the decision of demonetization and implementation of GST. It continued to attract the foreign investors in India.

b) Trade Openness(TO): The value of the Karl Pearson's coefficient is very low in trade openness, soon it will get revive because after the make in India campaigning of Government the trade openness has been more familiar to the investors; recently India has recorded a jump of 23 positions in "Ease of Doing Business."

c) Exports: It has a strong positive correlation between FDI and export in fact the higher the export is attracting the foreign companies to manufacture the products in India.

d) Imports: The high degree of correlation reveals the interest of investors and shows the greater the demand and expansion of business via domestic production.

e) Industrial Production Index (IPI: The high degree of correlation with industrial index discloses the fact that there are more possibilities for investors.

f) Exchange Rate: The increasing exchange rates of the country always attract the foreign players to establish their manufacturing units in such country.

g)Gross Fixed Capital Formation (GFCF): The GFC ratio is also the reason for MNCs to set their units by using the host country's resources. It is highly correlated.

h) Fiscal Deficit: Rise in the fiscal deficit does not attract the FDI some time it happens because of the hike in the price of petroleum products.

Table-II Regression Results (2009-2019)

\begin{tabular}{|l|c|c|c|c|}
\hline Variables & Coefficients & Standard Error & t-Statistics & P-Value \\
\hline Constant Term & 17.245 & 8.25 & 5.283 & 0.035 \\
\hline GDP & -2.53 & 0.79 & -2.14 & 0.024 \\
\hline Trade Openness & 1.23 & 0.92 & 1.987 & 0.046 \\
\hline Inflation (WPI) & 7.26 & 4.32 & 3.428 & 0.002 \\
\hline $\begin{array}{l}\text { Foreign Exchange } \\
\text { Reserve }\end{array}$ & -1.046 & 0.43 & -2.12 & 0.037 \\
\hline
\end{tabular}

Published By: 
This model can be expressed as:

FDI= f (GDP, TO, INF, FOREX)

Note: $*$ = Significant at 0.05 level

$\mathbf{R}^{2}=0.82$

$\mathbf{R}^{2}=0.79$ Adjusted

F - Value $=24.73 *$

Interpretation of above Analysis: The regression results of these factors again disclose that GDP, Trade Openness and Inflation are economic driving forces for foreign direct investment inflows to India after deregulation period whereas Foreign exchange works as the curb force to catch hold FDI inflows in India. All the variables incorporated in this model determine their predicted signs except single variable (i.e. Foreign Exchange Reserves) which deviate from their expected value. However, all these macroeconomic variables are highly significant at $5 \%$ level of confidence.

Although, (See Table III) it is comprehensible the GVA for different sectors during the ruling of Congress as well as BJP. This table let us know how the GVA has been improved after the campaigning of Make in India by Modi Government. Gross value added (GVA) estimates the value of goods and services produced or manufactured in a territory, industry or sector of an economy.

Table-III GVA Growth in different sectors after Make in India Campaigning

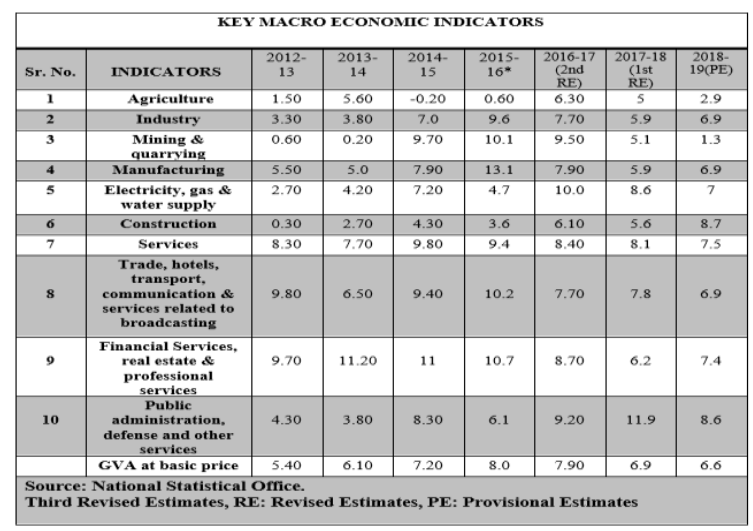

We can easily calculate the Gross value added for all sectors by using the following formula.

GVA at factor cost $=$ GVA at basic prices - production taxes minus production subsidies. GDP $=\Sigma \mathrm{GVA}$ at basic prices + product taxes - product subsidies, we can also write it as: GDP $=$ GVA + DITS, where DITS is the difference between indirect taxes and subsidies.

\section{GDP Growth of India during the Congress and BJP Government}

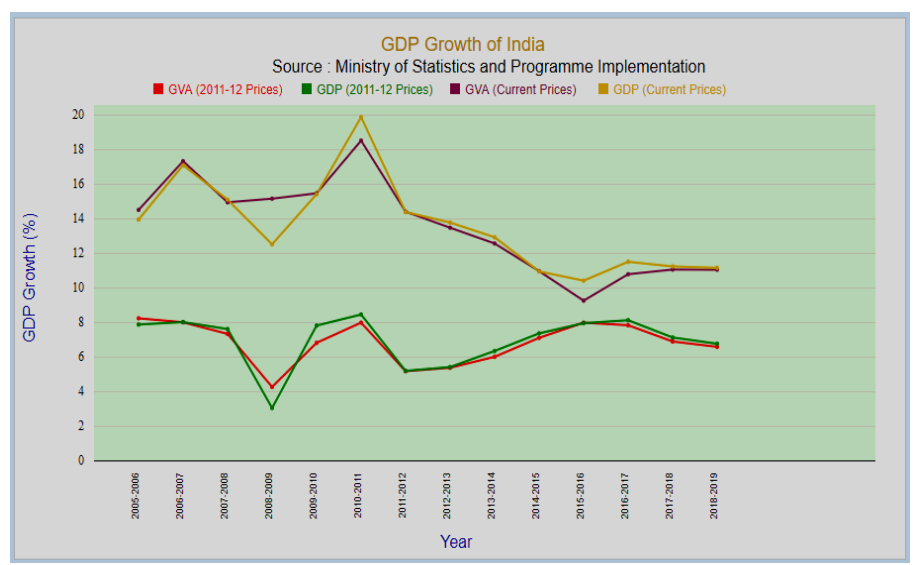

Figure 1 Showing the GDP

When the congress party was ruling as a Central Government, the GDP rate was good enough to accelerate the economic growth that time the Prime Minister was Dr. Manmohan Singh. Suddenly at the end of the 2012 the economic policy doesn't work and GDP come down heavily as a result of this the congress become the gone case and BJP came into force. Prime Minister Narendra Modi has taken the decision of demonetization then GST regime these policies somehow affect the growth of the country but it was mandatory to modify the taxation policy for the betterment of all states. The real GDP growth of India at constant (2011-12) prices in the year 2018-19 is estimated at 6.81 percent in comparison to the growth rate of 7.17 percent in 2017-18. The growth in gross domestic product was slowest since 2014-15. The previous low was $6.39 \%$ in 2013-14.In parallel to adopt these heavy weight policies the Indian Government has taken several actions to achieve the sustainable economic growth.

Table IV FDI INFLOW TO INDI

\begin{tabular}{|c|c|c|c|c|c|c|c|c|}
\hline \multirow{3}{*}{$\begin{array}{l}\text { S. } \\
\text { No }\end{array}$} & \multirow{3}{*}{\begin{tabular}{|l|} 
Financial \\
Year \\
(April- \\
March)
\end{tabular}} & \multicolumn{6}{|c|}{ OREIGN DIRECT INVESTMIENT (FDI) } & \multirow{3}{*}{$\begin{array}{l}\text { Investment b } \\
\text { FII's Foreigy } \\
\text { Institutional } \\
\text { Investors } \\
\text { Fund } \\
\text { (net) }\end{array}$} \\
\hline & & \multirow[b]{2}{*}{$\begin{array}{l}\text { Equity } \\
\text { FIPB Route/ } \\
\text { RBI's } \\
\text { Automatic } \\
\text { Route/ } \\
\text { Acquisition } \\
\text { Route }\end{array}$} & \multirow[b]{2}{*}{\begin{tabular}{|l|} 
Equity \\
capital of \\
uni- \\
incorporated \\
bodies \#
\end{tabular}} & \multirow{2}{*}{\begin{tabular}{|l} 
Re- \\
invested \\
earnings \\
+
\end{tabular}} & \multirow{2}{*}{$\begin{array}{l}\text { Other } \\
\text { capital } \\
++\end{array}$} & \multicolumn{2}{|c|}{\begin{tabular}{|l|} 
FDIFLOWS INTO \\
NNDIA
\end{tabular}} & \\
\hline & & & & & & \begin{tabular}{|l} 
Total \\
Flows FDI
\end{tabular} & 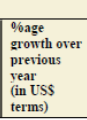 & \\
\hline & & & \multicolumn{5}{|c|}{ FINANCLAL YEARS 2000-01 TO 2018-19 } & \\
\hline 1. & $2000-01$ & 2,339 & 61 & 1,350 & 279 & 4,029 & & 1,847 \\
\hline 2. & 2001-02 & 3,904 & 191 & 1,645 & 390 & 6,130 & $(+) 52 \%$ & 1,505 \\
\hline 3. & $2002-03$ & 2,574 & 190 & 1,833 & 438 & 5,035 & $(-) 18 \%$ & 377 \\
\hline 4. & $2003-04$ & 2,197 & 32 & 1,460 & 633 & 4,322 & $(-) 14 \%$ & 10,918 \\
\hline 5. & 2004-05 & 3,250 & 528 & 1,904 & 369 & 6,051 & $(+) 40 \%$ & 8,686 \\
\hline 6. & $2005-06$ & 5,540 & 435 & 2,760 & 226 & 8,961 & $(+) 48 \%$ & 9,926 \\
\hline 7. & $2006-07$ & 15,585 & 896 & 5,828 & 517 & 22,826 & (+) $155 \%$ & 3,225 \\
\hline 8. & $2007-08$ & 24,573 & 2,291 & 7,679 & 300 & 34,843 & $(+) 53 \%$ & 20,328 \\
\hline 9. & 2008-09 & 31,364 & 702 & 9,030 & 777 & 41,873 & $(+) 20 \%$ & $(-) 15,017$ \\
\hline 10. & $2009-10$ & 25,600 & 1,540 & 8,668 & 1,931 & 37,745 & $(-) 10 \%$ & 29,048 \\
\hline 11. & 2010-11 & 21,376 & 874 & 11,939 & 658 & 34,847 & $(-) 08 \%$ & 29,422 \\
\hline 12. & 2011-12 & 34,833 & 1,022 & 8,206 & 2,495 & 46,556 & (+) $34 \%$ & 16,812 \\
\hline 13. & 2012-13 & 21,825 & 1,059 & 9,880 & 1,534 & 34,298 & $(-) 26 \%$ & 27,582 \\
\hline 14 & 2013-14 & 24,299 & 975 & 8,978 & 1,794 & 36,046 & $(+) 5 \%$ & 5,009 \\
\hline 15. & 2014-15 & 30,933 & 978 & 9,988 & 3,249 & 45,148 & $(+) 25 \%$ & 40,923 \\
\hline 16. & 2015-16 & 40,001 & 1,111 & 10,413 & 4,034 & 55,559 & $(+) 23 \%$ & $(-) 4,016$ \\
\hline 17. & $\begin{array}{c}2016-17 \\
(P)\end{array}$ & 43,478 & 1,223 & 12,343 & 3,176 & 60,220 & $(+) 8 \%$ & 7,735 \\
\hline 18. & $\begin{array}{c}2017-18 \\
(\mathrm{P})\end{array}$ & 44,857 & 664 & 12,542 & 2,911 & 60,974 & (+) $1 \%$ & 22,165 \\
\hline 19. & $\begin{array}{c}2018-19 \\
\text { (P) }\end{array}$ & 44,366 & 693 & 13,570 & 5,746 & 64,375 & (+) $6 \%$ & $(-3,587$ \\
\hline \multicolumn{2}{|c|}{$\frac{\text { CUMMCLATINE }}{\text { TOTIL }}$} & 422,900 & 15,465 & 140,016 & 31,457 & 609,838 & - & 212,888 \\
\hline
\end{tabular}

Source: RBI's Bulletin March, 2019 dt.11.05.2019 (Table No. 34 - FOREIGN INVESTMENT INFLOWS). 


\section{Does Political Ideology Affect the Growth of Indian Economy? (A Factor of FDI and Make in India as a Structural Transformation)}

Discussion: The above table accommodates the FDI data of both Government Congress as well as Bharatiya Janta Party. The entire world was facing the global economic (2008-09) crisis then India was enjoying its sustainable growth. In spite of these the Indian Prime Minister Dr. Manmohan Singh achieved high growth rate compare to the world's largest economies. This model of European countries adopted by Congress Government get flopped at the end of year 2012, as a result of this congress could not revive the economy as well as themselves. In the year $2014 \mathrm{Mr}$.Narendra Modi took the oath of Prime Minister and starts a lot of schemes to revive this downfall of dipped economy but the growth was stopped at a point when he took the decision of demonetization that pushed back the growth of the nation, again Mr. Modi passed GST Bill to ensure the better supervision for all states it was quite good decision in the history of Indian Financial System. But new policy takes some time to take off and now it's working smoothly and finally government succeeded to achieve higher taxation revenue.

The combination of political will, socioeconomic driving forces, strong institutional structure, low level of corruption, and favorable legal environment has supported to lay the underpinning for economic growth, while India's open trade policies will be the keys in sustaining growth.

\section{TABLE V SECTOR ATTRACTING HIGHEST FDI} INFOWS IN INDIA

\begin{tabular}{|c|c|c|c|c|c|c|}
\hline Ranks & SECTORS & $\begin{array}{l}2016-17 \\
\text { (April - } \\
\text { March) }\end{array}$ & $\begin{array}{l}2017-18 \\
\text { (April- } \\
\text { March) }\end{array}$ & $\begin{array}{l}2018-19 \\
\text { (April,18- } \\
\text { March,19) }\end{array}$ & $\begin{array}{l}\text { Cumulative } \\
\text { Inflows (April, } \\
00- \\
\text { March, 19) }\end{array}$ & $\begin{array}{l}\% \text { age to } \\
\text { total Inflows } \\
\text { (In terms of } \\
\text { USS) } \\
\end{array}$ \\
\hline 1. & SERVICES SECTOR ** & $\begin{array}{l}58,214 \\
(8,684)\end{array}$ & $\begin{array}{l}43,249 \\
(6,709)\end{array}$ & $\begin{array}{l}63,909 \\
(9,158)\end{array}$ & $\begin{array}{l}416,301 \\
(74,149)\end{array}$ & $18 \%$ \\
\hline 2. & $\begin{array}{l}\text { COMPUTER SOFTWARE \& } \\
\text { HARDWARE }\end{array}$ & $\begin{array}{l}24,605 \\
(3,652)\end{array}$ & $\begin{array}{l}39,670 \\
(6,153)\end{array}$ & $\begin{array}{l}45,297 \\
(6,415)\end{array}$ & $\begin{array}{l}221,756 \\
(37,238)\end{array}$ & $9 \%$ \\
\hline 3 & TELECOMMUNICATIONS & $\begin{array}{l}37,435 \\
(5,564)\end{array}$ & $\begin{array}{l}39,748 \\
(6,212)\end{array}$ & $\begin{array}{l}18,337 \\
(2,668)\end{array}$ & $\begin{array}{l}188,249 \\
(32,826)\end{array}$ & $8 \%$ \\
\hline 4. & 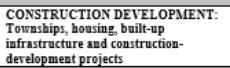 & $\begin{array}{l}703 \\
(105)\end{array}$ & $\begin{array}{l}3,472 \\
(540)\end{array}$ & $\begin{array}{l}1,503 \\
(213)\end{array}$ & $\begin{array}{l}119,614 \\
(25,046)\end{array}$ & $6 \%$ \\
\hline 5. & TRADING & $\begin{array}{l}15,721 \\
(2,338)\end{array}$ & $\begin{array}{l}28,078 \\
(4,348)\end{array}$ & $\begin{array}{l}30,963 \\
(4,462)\end{array}$ & $\begin{array}{l}143,599 \\
(23,021)\end{array}$ & $5 \%$ \\
\hline 6. & AUTOMOBILE INDUSTRY & $\begin{array}{l}10,824 \\
(1,609)\end{array}$ & $\begin{array}{l}13,461 \\
(2,090)\end{array}$ & $\begin{array}{l}18,309 \\
(2,623)\end{array}$ & $\begin{array}{l}123,989 \\
(21,387\end{array}$ & $5 \%$ \\
\hline 7. & $\begin{array}{l}\text { CHEMICALS (OTHER THAN } \\
\text { FERTILIZERS) }\end{array}$ & $\begin{array}{l}9,397 \\
(1,393)\end{array}$ & $\begin{array}{r}8,425 \\
(1,308)\end{array}$ & $\begin{array}{l}13,685 \\
(1,981)\end{array}$ & $\begin{array}{l}91,062 \\
(16,582)\end{array}$ & $4 \%$ \\
\hline 8. & $\begin{array}{l}\text { DRUGS \& } \\
\text { PHARMACEUTICALS }\end{array}$ & $\begin{array}{l}5,723 \\
8572\end{array}$ & 6,502 & 1,842 & $\begin{array}{l}84,165 \\
84,1633)\end{array}$ & $4 \%$ \\
\hline 9. & $\begin{array}{l}\text { CONSTRUCTION } \\
\text { (INFRASTRUCTURE) } \\
\text { ACTIVIIIES }\end{array}$ & $\begin{array}{l}12,478 \\
(1,861)\end{array}$ & $\begin{array}{l}17,571 \\
(2,730)\end{array}$ & $\begin{array}{l}15,927 \\
(2,258)\end{array}$ & $\begin{array}{l}93,873 \\
(14,805)\end{array}$ & $4 \%$ \\
\hline 10. & POWER & $\begin{array}{c}7,473 \\
(1,113)\end{array}$ & $\begin{array}{l}10,473 \\
(1,621)\end{array}$ & $\begin{array}{c}7,330 \\
(1,106)\end{array}$ & $\begin{array}{l}77,889 \\
(14,316)\end{array}$ & $3 \%$ \\
\hline
\end{tabular}

Source: RBI's Bulletin March, 2019 dt.11.05.2019 (Annex.B FOREIGN DIRECT INVESTMENT INFLOWS).

Discussion: The statistics display the highest attractive sector to FDI is service sector in India. These socioeconomic structural transformations will encourage to the investors to take the privilege of lower wage, tax exemption and favorable policy regime to ensure India as a dream destination. The listed ten sectors (See Table V) have the highest FDI flow in India, apart from being a socio economic driver of the country FDI is also a debt free financial resource to the economy. The present Government succeeded to mesmerize the Foreign Investors in few sectors but they need to work and ensure the planning for other sectors unless until the remaining sector like Textile Industry, Agricultural sectors Education and Mining etc. would not have been grow we cannot expect the urbanization of rural India. The Modi Government must be focused on the rural area for the parallel growth of the nation otherwise the "Rich get richer and Poorer get poorer" will be

true. If it happens then there is no meaning of this growth for India.

The Road Ahead: Within the short period of time, we have many examples and announcements. In December 2015 at the end of the year 'Micromax mobile company' announced to establish their three new manufacturing plants in Rajasthan. Japan announced to invest USD 12 billion for Make in India-related projects, called the "Japan-India Make-in-India Special Finance Facility" after the meeting of Japanese counterpart 'Shinzo Abe' with 'Prime Minister Narendra Modi'. Huawei has started its new Research and Development (R\&D) centre in Bengaluru and the company is supposed to build up a manufacturing unit of telecom hardware in Chennai. A France based company LH Aviation inscribed a Memorandum of Understanding (MoU) with OIS Advanced Technologies to set a production unit in India for the production of drones. The Foxconn Company decided to bring USD 5 billion within five years for Research and producing a hi-tech semiconductor manufacturing facility in Maharashtra. Samsung would have started the manufacturing of Samsung Z1 mobile in Noida, apart from this the General Motors declared an investment of USD 1 billion to begin production of cars in Delhi. This is only the tilt of the iceberg as there are so many proposals in the pipeline for different sectors. It said that notable megadeals included the acquisition of Flipkart, India's biggest e-commerce platform, by American giant Wal-Mart. In addition, telecommunication deals involving Vodafone (UK) and American Tower (US) amounted to USD 2 billion.

\section{FINDINGS AND CONCLUSION}

For a developing economy like that of India Political Ideology and FDI inflows play an important role to bridge the gap between domestic savings and investment to maintain a sustainable economic growth. The inward FDI is argued to have visible impact on the real economy through its effect on important macroeconomic variables. While the Modi government has been successful in few sectors, especially in cutting red tape, India has been jumped 30 places in the World Bank's ranking of "Ease of Doing Business" to break into the top 100 nations. However, according to reports and economists, manufacturing in India's economic output has tapered in the get up of demonetization and the confused launch of a goods and services tax (GST). While manufacturing sector has been evident as one of the smooth and fastest growing sectors in India but with services sector picking up in the early 2000s, manufacturing saw a fall in its contribution to overall GDP. The Modi Government somehow has been successful to achieve the sustainable development of the economy by using the welfare principle of economics and proved that the linkage of socioeconomic driving forces with the resources of nation leads the parallel growth of the country. And it look like that the world is ready to clinch this vision, which is previously set on a pathway to turn into an actuality. 


\section{REFERENCES:}

1. Agarwal, Gaurav and Khan M. A., "Impact of FDI on GDP: A Comparative Study of China and India"International Journal of Business and Management Vol. 6, No. 10; October (2011)

2. Aneja Puneet. Make in India-A new paradigm for socio-economic growth in India. PARIPEX- Indian Journal of Research. 2016.

3. Bhattacharyya Jita, Bhattacharyya Mousumi (2012), - Impact of Foreign Direct Investment and Merchandise and Services Trade of the Economic growth in India: an Empirical studyll, IIMS Journal of Management Science, Vol. 3(1).

4. Christian Bjørnskov "Does Political Ideology Affect Economic Growth"? Public Choice Vol. 123, No. 1/2 (Apr., 2005), pp. 133-146 Published by: Springer.

5. Echeverri-Gent, John, 2001, Political Economy of India's Fiscal and Financial Reforms, CREDPR Working Paper No. 105 (Stanford University: Center for Research on Economic Development and Policy Reform).

6. Goyal Kaur Singh. Role of HR and Financial Services in Making 'Make in India' campaign a success. IOSR Journal of Business and Management. 2015, 20-24.

7. Gerwin, M., \& Bergmann, C. (2012). Geopolitical relations and regional restructuring: the case of the Kumaon Himalaya, India. Erdkunde, 91-107.

8. Ramana KV. Make in India: An illusion or a reality project. International Journal of Academic Research. 2015.

9. Rosetta Morris, Abdul Aziz, (2011) "Ease of doing business and FDI inflow to Sub-Saharan Africa and Asian countries", Cross Cultural Management: An International Journal, Vol. 18 (4), pp. 400 - 411.

10. Saini A., Law S. H., Ahmad A. H. (2010), "FDI and economic growth: New evidence on the role of financial markets Economics Letter Volume 107, Issue 2, May 2010, Pages 211-213

11. Sangwan Seema. Making Make in India realistic: role of FDI International Journal of Applied Research. 2015.

12. Shettar Rajeshwari M. Impact of Make in India campaign: A Global Perspective. Journal of Research in Business and Management. 2017, 01-06.

13. Shettar Rajeshwari M. Deposit Mobilization and Socio - Economic Impact: A Case Study of Union Bank Of India IOSR Journal of Engineering (IOSRJEN) www.iosrjen.org ISSN (e): 2250-3021, ISSN (p): 2278-8719 Vol. 04, Issue 05 (May. 2014),V4 PP 21-26

14. Singh S., Singh M. (2011), - Trends and prospects of FDI in Indiall, Economic Affairs, Vol. 56 (1).

15. Singh Y., Bhatnagar A. (2011), -FDI in India and China; A comparative analysis, International Journal of Business Economics and Management Research, Vol. 2 (1).

16. Soundhariya $\mathrm{S}$. Make in India-Scheme for Transforming India. Global Journal for Research Analysis. 2015.

17. Vijayragwan T. Make in India and its strength to become India's manufacturing hub. International Journal of Energy, Business and Enterprise Applications. 2015.

18. Handbook of Statistics on Indian Economy. Reserve Bank of India. 2019.

19. http://www.makeinindia.com/policy/foreign-direct-investment https://dbie.rbi.org.in/DBIE/dbie.rbi?site=home

\section{AUTHORS PROFILE}

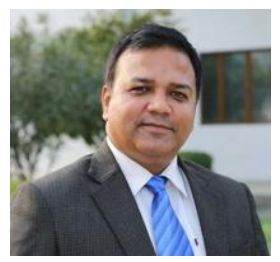

Dr. Anshul Sharma is a man of Finance having more than 15 years experience of P.G. teaching with institution of high repute and 4 years' experience of Banking. He is working as Head of the Department of Management. He has a rich experience of administration in varied capacities including Dean, Director, Procter, Chief Editor, Centre Superintendent, Examination Controller, Research Guide, Paper Setter, Placement Coordinator and Head - Cultural Activities and has been Member of Academic Council, Executive Council, Faculty Board and Board of Studies in different Universities. Along with good administrative experience he has a rich experience of research guidance and publications and is associated with different journals as Member of Editorial Team and Reviewer. He has conducted Workshops and attended number of Seminars, Workshops and
FDP's as a Resource Person. He has around 20 international and 5 national publications in various journals.

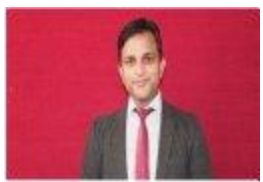

FarmanAli, he is Assistant Professor at MBA department at Uttaranchal University, Dehradun. He is UGC-NET qualified and he is pursuing his $\mathrm{PhD}$. 